\title{
Modified cycloartanes with improved inhibitory effect on SGLT-mediated glucose uptake in human renal proximal tubular cells
}

\author{
Napason Chabang ${ }^{\mathrm{a}}$, Sirima Soodvilai ${ }^{\mathrm{b}}$, Bamroong Munyoo ${ }^{\mathrm{c}}$, Patoomratana Tuchinda ${ }^{\mathrm{c}}$, \\ Sunhapas Soodvilai ${ }^{\mathrm{c}, \mathrm{d}, *}$ \\ a School of Bioinnovation and Bio-based Product Intelligence, Faculty of Science, Mahidol University, \\ Bangkok 10400 Thailand \\ b Department of Pharmaceutical Technology, College of Pharmacy, Rangsit University, Pathum Thani \\ 12000 Thailand \\ ${ }^{c}$ Excellent Center for Drug Discovery, Mahidol University, Bangkok 10400 Thailand \\ d Research Center of Transporter Protein for Medical Innovation, Department of Physiology, Faculty of \\ Science, Mahidol University, Bangkok 10400 Thailand
}

*Corresponding author, e-mail: sunhapas.soo@mahidol.ac.th

Received 25 Jun 2020

Accepted 22 Dec 2020

\begin{abstract}
Sodium/glucose co-transporters (SGLTs) play an important role in renal glucose reabsorption. Inhibition of SGLT2 by derivatives of $O$-glucoside phlorizin dihydrochalcones has been approved for treatment of type 2 diabetes. The present study searches for the inhibitory effect of schisandronic acid (4), a cycloartane isolated from leaves and twigs of Gardenia collinsae Craib, and its derivatives 1-3 on SGLTs in human renal proximal tubular cells. SGLT-mediated glucose uptake in human renal proximal tubular cells was performed by measuring accumulation of ${ }^{3} \mathrm{H}$-deoxyglucose $\left({ }^{3} \mathrm{H}-2 \mathrm{DG}\right)$ in human renal proximal tubular cell lines, kidney 2 (HK-2), and RPTEC/TERT1 cells. Schisandronic acid slightly inhibited ${ }^{3} \mathrm{H}-2 \mathrm{DG}$ accumulation in HK-2 cells. Compounds 1 and 2 exhibited significant inhibition of transport activity of SGLT in HK-2 cells. The half inhibitory concentration $\left(\mathrm{IC}_{50}\right)$ showed that compound 2 was found to be the most potent with $\mathrm{IC}_{50}$ of $32.18 \mu \mathrm{M}$. In addition, the inhibitory effect of compound 2 was not a result of cytotoxicity. Reduction of $\mathrm{IC}_{50}$ of compound 2 on ${ }^{3} \mathrm{H}-2 \mathrm{DG}$ uptake $(16.81 \mu \mathrm{M})$ was found in RPTEC/TERT1 cells that mainly express SGLT2. This study represents the first reported evidence of cycloartane derivatives inhibiting SGLT-mediated glucose uptake in human renal proximal tubular cells.
\end{abstract}

KEYWORDS: cycloartane, sodium/glucose co-transporters, diabetes, kidney, schisandronic acid

\section{INTRODUCTION}

Diabetes mellitus (DM) is a metabolic disorder characterized by glucose intolerance and changes in lipid and protein metabolism. Moreover, long-term diabetic patients who are treated ineffectively suffer from complications of retinopathy, nephropathy, and peripheral neuropathy [1]. The current therapies for type- 2 diabetes include mainly oral antidiabetic drugs such as sulfonylureas, biguanides, $\alpha$-glucosidase inhibitors, thiazolidinediones, and dipeptidyl peptidase-4 (DPP-4) inhibitors, which are used as monotherapy or in combination [2-6]; however, hypoglycemic effect and metabolic acidosis are reported during treatment with these drugs [3]. Therefore, safe and more effective anti-diabetic drugs are urgently needed.
A new target for treatment of DM type 2 has been discovered. Currently, inhibition of renal glucose reabsorption by inhibiting sodium glucose transporter 2 (SGLT2), which is a major glucose transporter responsible for renal glucose reabsorption, is introduced as a new target for treatment of DM type 2 [7-10]. Inhibition of renal glucose reabsorption is a novel strategy for achieving glucose control in type 2 diabetes mellitus $[8,11]$. The prototypic compound in this class is phlorizin, a dihydrochalcone $\mathrm{O}$-glycoside isolated from bark of apple tree. However, phlorizin is not used in diabetic patients because of its unpleasant adverse drug reactions including osmotic diarrhea [12]. Later on, the derivatives of phlorizin were developed in order to reduce the adverse effects by increasing selectivity for SGLT2 selectively expressed in renal proximal 
tubular cells. Recent work on targeting Toll-like receptor 4 level in monocyte and CD14+CD16+ monocyte ratio for early diagnosis for the benefit of reducing complications of diabetic nephropathy has been reported [13].

Schisandronic acid is a known cycloartane triterpenoid, commonly found in Schisandra and Kadsura species (family: Schisandraceae). This triterpenoid was first isolated from the wooden part of Schizandra nigra Max. [14] and later from Illicium verum [15] and Schisandra propinqua [16]. Several biological activities of schisandronic acid have been reported. Cell viability of human decidual cells was reduced by about $50 \%$ after treatment of the cell with $20 \mu \mathrm{g} / \mathrm{ml}$ of schisandronic acid for $24 \mathrm{~h}$ [16]. Schisandronic acid showed a moderate cytotoxic activity against several cancer cells such as leukemia [17], hepatocellular carcinoma, and oropharyngeal epidermoid carcinoma $9[18,19]$. In addition to antitumor effect, schisandronic acid has been shown to exhibit anti-HIV activity [19]. Furthermore, both tetracyclic and pentacyclic triterpenoids have been published to date to exert potential anti-diabetic effects through various mechanisms in various cell types. For example, they increased glucose uptake and glycogen synthesis in insulin resistant human HepG2 cells [20]. Therefore, it will be possible that schisandronic acid, the triterpenoid isolated from the methanol extract of leaves and twigs of Gardenia collinsae, may have an effect on glucose uptake. In this study, the effects of schisandronic acid and its modified derivatives on SGLT-mediated glucose uptake in human renal proximal tubular cells are investigated.

\section{MATERIALS AND METHODS}

\section{General experimental procedures}

Melting points (uncorrected) were recorded on a digital Electrothermal apparatus. Optical rotations were determined on a JASCO DIP 370 digital polarimeter using a $50 \mathrm{~mm}$ microcell $(1 \mathrm{ml})$. IR $(\mathrm{KBr})$ and $\mathrm{UV}$ (in $\mathrm{EtOH}$ or $\mathrm{MeOH}$ ) spectra were recorded on a Perkin-Elmer 2000 FT-IR and JASCO 530 spectrometers, respectively. The $400 \mathrm{MHz}{ }^{1} \mathrm{H}$ NMR and $100 \mathrm{MHz}{ }^{13} \mathrm{C}$ NMR spectra were recorded on Bruker Ascend 400 spectrometer, in $\mathrm{CDCl}_{3}$ using TMS as internal standard. EIMS were recorded at $70 \mathrm{eV}$ (probe) on a Thermal Finnigan Polaris Q mass spectrometer. The HR-TOF-MS were recorded on a Micromass model VQ-Tof-2 spectrometer. Silica gel 60H (Merck, 70-230 mesh) was used for column chromatography, whereas preparative TLC was car- ried out with silica gel plates (Merck, $20 \times 50 \mathrm{~cm}$, thickness $0.5 \mathrm{~mm}$ ). The pre-coated TLC plates 60 F254 (Merck, $20 \times 20 \mathrm{~cm}$, thickness $0.2 \mathrm{~mm}$ ) were used for analytical purposes. The bands were visualized under ultraviolet light at $\lambda_{\max } 254$ and $366 \mathrm{~nm}$. Schsandronic acid (4) was isolated from leaves and twigs of Gardenia collinsae Craib. All solvents used for extraction and isolation were distilled prior to use at their boiling point ranges.

\section{Isolation of schsandronic acid (4) from the extract of leaves and twigs}

\section{Plant material}

The leaves and twigs of Gardenia collinsae Craib were collected from Khao Trakrup, Ang Rue Nai Botanical Garden, Srakaew Province of Thailand in May 2004. A voucher specimen (BKF 62731) has been deposited at the Forest Herbarium, Department of National Park, Wildlife and Plant Conservation, Ministry of Natural Resources and Environment, Bangkok 10220 Thailand.

\section{Extraction and isolation}

The air-dried and finely powdered leaves and twigs of $G$. collinsae $(22.8 \mathrm{~kg}$ ) were successively percolated with methanol (61 $1 \times 5$ days $\times 5$ times) at room temperature, followed by filtration. The filtrates were combined and evaporated to dryness under reduced pressure to yield a crude methanol extract (2002 g).

The methanol extract (1048 g) was suspended in water $(2.5 \mathrm{l})$ and partitioned with chloroform ( $21 \times 6$ times) and n-butanol ( $31 \times 2$ times), respectively. Removal of solvents under reduced pressure afforded the chloroform fraction (420 g), n-butanol fraction $(253 \mathrm{~g})$, and water fraction $(332 \mathrm{~g})$. The chloroform fraction (420 g) was subjected to a coarse separation by column chromatography over silica gel $(1.0 \mathrm{~kg})$. Gradient elution started with hexane, gradually enriched with acetone, followed by increasing amount of methanol in acetone, and finally with methanol. All fractions were collected (500 ml each), monitored by TLC, and combined on the basis of their TLC characteristics. The solvents were evaporated to dryness to provide 8 separated fractions (A1-A8).

Fraction A3 (34.1 g), eluted by $10 \%$ acetonehexane, was further separated by column chromatography (2-10\% acetone-hexane) to give fractions B1-B5 after combination and evaporation to dryness. Addition of EtOH- $\mathrm{CH}_{2} \mathrm{Cl}_{2}$ to fraction B4 
(20.5 g, eluted with 7\% acetone-hexane) provided pure schisandronic acid (4) (1.76 g) as a white powder. Further purification of the residue $(17.7 \mathrm{~g})$ by column chromatography (gradient EtOAc-hexane) yielded fractions $\mathrm{C} 1-\mathrm{C} 3$ after combination and evaporation to dryness. Fraction C2 (15.71 g, eluted with 30-50\% EtOAc-hexane) afforded an additional amount of schisandronic acid (4) (10.8 g) after recrystallization from $\mathrm{EtOH}-\mathrm{CH}_{2} \mathrm{Cl}_{2}$.

\section{Preparation of compound 1}

MCPBA (70\%, $119.0 \mathrm{mg}, 0.48 \mathrm{mmol}, 2.2$ equiv.) and anhydrous $\mathrm{NaHCO}_{3}(55.5 \mathrm{mg}, 0.66 \mathrm{mmol}, 3$ equiv.) were added to a stirred solution of schisandronic acid (4) (100 mg, $0.22 \mathrm{mmol}$ ) in dried $\mathrm{CH}_{2} \mathrm{Cl}_{2}(6 \mathrm{ml})$. The reaction mixture was stirred at room temperature for $4 \mathrm{~h}$ (Scheme 1), diluted with $\mathrm{CH}_{2} \mathrm{Cl}_{2}(15 \mathrm{ml})$, and then washed with a 1:1 mixture of $5 \% \mathrm{Na}_{2} \mathrm{~S}_{2} \mathrm{O}_{3}: 5 \% \mathrm{NaHCO}_{3}(3 \times 20 \mathrm{ml})$ to remove excess MCPBA. The combined organic layer was washed with $\mathrm{H}_{2} \mathrm{O}(3 \times 20 \mathrm{ml})$, dried with anhydrous $\mathrm{Na}_{2} \mathrm{SO}_{4}$, filtered, and evaporated to dryness to afford a white solid (122.8 mg). Purification by preparative TLC, eluted with EtOAc:hexane (3:7), provided compound 1 (55.7 $\mathrm{mg}, 68 \%)$.

1: m.p. $133.1-135.4^{\circ} \mathrm{C} .[\alpha]_{589}^{29}+33.2$ (c 0.0074, pyridine- $\left.\mathrm{d}_{5}\right)$. UV $\lambda_{\max }^{\mathrm{EtOH}} \mathrm{nm}(\log \varepsilon): 225$ (3.60). FTIR (KBr) $v_{\max } \mathrm{cm}^{-1}: 3448,2942,2871,1701$, 1638, 1459, 1384, 1259, 1193, 1159, 1113, 1034, 1011, 980, 897, 780, 609. ${ }^{1} \mathrm{H}$ NMR $(400 \mathrm{MHz}$, $\left.\mathrm{CDCl}_{3}\right), \delta: 6.02(1 \mathrm{H}, t, J=6.9 \mathrm{~Hz}, \mathrm{H}-24), 2.64$ $(1 \mathrm{H}$, obsc, H-2a), $2.62(1 \mathrm{H}$, obsc, $\mathrm{H}-2 \mathrm{~b}), 2.52(1 \mathrm{H}$, obsc, H-23a), $2.42(1 \mathrm{H}, o b s c, \mathrm{H}-23 \mathrm{~b}), 2.03(1 \mathrm{H}, o b s c$, $\mathrm{H}-11 \mathrm{a}), 2.02(1 \mathrm{H}$, obsc, H-5), $1.88(1 \mathrm{H}$, obsc, $\mathrm{H}-$ 16a), 1.85 (3H, s, H-27), $1.74(1 \mathrm{H}, o b s c, \mathrm{H}-1 \mathrm{a})$, $1.74(1 \mathrm{H}$, obsc, $\mathrm{H}-6 \mathrm{a}), 1.70(2 \mathrm{H}$, obsc, $\mathrm{H}-12), 1.61$ (1H, obsc, H-17), 1.57 (1H, obsc, H-22a), $1.55(1 \mathrm{H}$, obsc, H-1b), $1.49(1 \mathrm{H}, o b s c, \mathrm{H}-7 \mathrm{~b}), 1.44(1 \mathrm{H}$, obsc, $\mathrm{H}-8$ ), 1.39 (3H, $s, \mathrm{H}-28$ ), 1.33 (3H, $s, \mathrm{H}-29), 1.29$ (1H, obsc, H-7a), 1.29 (1H, obsc, H-16b), $1.29(1 \mathrm{H}$, obsc, H-20), 1.18 (1H, obsc, H-22b), 1.04 (1H, obsc, $\mathrm{H}-11 \mathrm{~b}), 1.00(1 \mathrm{H}$, obsc, H-7b) $0.90(3 \mathrm{H}, s, \mathrm{H}-$ 30), $0.86(3 \mathrm{H}, s, \mathrm{H}-18), 0.83(1 \mathrm{H}, d, J=6.4 \mathrm{~Hz}$, $\mathrm{H}-21), 0.65(1 \mathrm{H}$, obsc, H-6b) $0.58(1 \mathrm{H}, b d, \mathrm{H}-$ 19b), $0.54(1 \mathrm{H}, d, J=4.6 \mathrm{~Hz}, \mathrm{H}-19 \mathrm{a}) .{ }^{13} \mathrm{C}$ NMR $\left(100 \mathrm{MHz}, \mathrm{CDCl}_{3}\right.$ ): 175.9 (C-3), 173.0 (C-26), 147.4 (C-24), 126.0 (C-25), 87.6 (C-4), 52.4 (C17), 50.0 (C-5), 49.0 (C-14), 49.0 (C-8), 45.1 (C13), 36.1 (C-20), 36.0 (C-15), 36.0 (C-22), 35.3 (C-2), 33.0 (C-12), 31.2 (C-28), 30.4 (C-1), 29.8 (C-19), 28.4 (C-16), 27.5 (C-11), 27.5 (C-10), 27.1 (C-23), 26.3 (C-6), 25.6 (C-7), 23.3 (C-29), 23.3 (C-9), 20.8 (C-27), 19.6 (C-30), 18.6 (C-18), 18.3
(C-21). ESI-MS $m / z: 493.3284[\mathrm{M}+\mathrm{Na}]^{+}$, (calcd. for $\mathrm{C}_{30} \mathrm{H}_{46} \mathrm{O}_{4} \mathrm{Na}$, 493.3294). EIMS $\mathrm{m} / \mathrm{z}$ (relative intensity): $370[\mathrm{M}]^{+}$(1), 355 (6), 327 (7), 313 (8), 287 (8), 259 (8), 255 (11), 235 (14), 211 (15), 201 (22), 187 (26), 174 (33), 161 (52), 159 (58), 133 (44), 120 (61), 106 (46), 92 (100), 77 (55), 67 (30), 51 (17).

\section{Preparation of compound 2}

A solution of compound 1 (50 $\mathrm{mg}, 0.11 \mathrm{mmol})$ in dry $\mathrm{MeOH}(2 \mathrm{ml})$ was added dropwise to a stirred solution of $\mathrm{NaOH}$ ( $4.7 \mathrm{mg}, 0.12 \mathrm{mmol}, 1.1$ equiv.) in dry $\mathrm{MeOH}(6 \mathrm{ml})$ at $0{ }^{\circ} \mathrm{C}$. The reaction mixture was left stirred at room temperature for $8 \mathrm{~h}$, and then acidified with $2 \mathrm{~N} \mathrm{HCl}$ until the $\mathrm{pH}$ was 6.5-7.0. After dilution with water $(50 \mathrm{ml})$ and extraction with $\mathrm{CH}_{2} \mathrm{Cl}_{2}(3 \times 20 \mathrm{ml})$, the combined organic layer was washed with $\mathrm{H}_{2} \mathrm{O}(3 \times 20 \mathrm{ml})$. The organic layer was dried with anhydrous $\mathrm{Na}_{2} \mathrm{SO}_{4}$, filtered, and evaporated to dryness to give a white solid. After evaporation to dryness, a white solid $(81.8 \mathrm{mg})$ was obtained. Purification by preparative TLC, eluted with $\mathrm{CH}_{3} \mathrm{COCH}_{3}$ :hexane (1:4), gave compound 2 (32.3 mg, 61\%).

2: m.p. $70.4-72.0^{\circ} \mathrm{C} .[\alpha]_{589}^{25}+15.4$ (c 0.0300, $\left.\mathrm{CHCl}_{3}\right)$. UV $\lambda_{\max }^{\mathrm{EtOH}} \mathrm{nm}(\log \varepsilon): 224$ (4.81). FTIR (KBr) $v_{\max } \mathrm{cm}^{-1}: 3458,2952,2873,1693,1641$, 1460, 1382, 1259, 1196, 1179, 1153, 1081, 923, 897, 780, 607. ${ }^{1} \mathrm{H}$ NMR (400 $\mathrm{MHz}, \mathrm{CDCl}_{3}$ ), $\delta$ : $6.07(1 \mathrm{H}, t, J=7.0 \mathrm{~Hz}, \mathrm{H}-24), 3.65(3 \mathrm{H}, s, \mathrm{H}-$ 31), $2.70(1 \mathrm{H}, o b s c, \mathrm{H}-2 \mathrm{a}), 2.61(1 \mathrm{H}, o b s c, \mathrm{H}-23 \mathrm{a})$, 2.27 ( $1 \mathrm{H}$, obsc, H-2b), 2.14 (1H, obsc, H-11a), 2.10 $(1 \mathrm{H}$, obsc, $\mathrm{H}-23 \mathrm{~b}), 1.92(3 \mathrm{H}, s, \mathrm{H}-27), 1.86(1 \mathrm{H}$, obsc, H-5), $1.86(1 \mathrm{H}, o b s c, \mathrm{H}-16), 1.66(2 \mathrm{H}, o b s c$, $\mathrm{H}-15), 1.60(2 \mathrm{H}, o b s c, \mathrm{H}-12), 1.58(1 \mathrm{H}$, obsc, $\mathrm{H}-$ 6a), $1.58(1 \mathrm{H}$, obsc, H-22a), $1.57(1 \mathrm{H}, o b s c, \mathrm{H}-$ 17), $1.52(1 \mathrm{H}, o b s c, \mathrm{H}-1 \mathrm{a}), 1.30(1 \mathrm{H}, o b s c, \mathrm{H}-11 \mathrm{a})$, 1.30 (1H, obsc, H-22b), 1.29 (1H, obsc, H-8), 1.29 (1H, obsc, H-20), $1.28(1 \mathrm{H}$, obsc, $\mathrm{H}-1 \mathrm{~b}), 1.28(1 \mathrm{H}$, obsc, H-7a), 1.25 (1H, obsc, H-16a), $1.25(3 \mathrm{H}, s$, $\mathrm{H}-28), 1.22$ (3H, $s, \mathrm{H}-29), 1.12(1 \mathrm{H}, o b s c, \mathrm{H}-7 \mathrm{~b})$, $0.96(3 \mathrm{H}, s, \mathrm{H}-30), 0.92(3 \mathrm{H}, s, \mathrm{H}-18), 0.89(3 \mathrm{H}$, $d, J=6.4 \mathrm{~Hz}, \mathrm{H}-21), 0.71(1 \mathrm{H}, o b s c, \mathrm{H}-6 \mathrm{~b}), 0.68$ (1H, $d, J=4.5 \mathrm{~Hz}, \mathrm{H}-19 \mathrm{~b}), 0.56(1 \mathrm{H}, d, J=4.5 \mathrm{~Hz}$, H-19a). ${ }^{13} \mathrm{C}$ NMR (100 MHz, $\mathrm{CDCl}_{3}$ ): 175.5 (C-3), 173.0 (C-26), 147.1 (C-24), 126.2 (C-25), 76.5 (C4), 52.6 (C-17), 51.8 (C-3), 49.1 (C-14), 48.9 (C-8), 45.4 (C-5), 45.1 (C-13), 36.3 (C-12), 36.2 (C-20), 36.0 (C-22), 33.4 (C-15), 32.3 (C-2), 31.9 (C-28), 31.2 (C-19), 30.6 (C-1), 28.5 (C-16), 27.2 (C-7), 27.2 (C-23), 26.8 (C-10), 26.5 (C-29), 26.0 (C-11), 25.7 (C-6), 23.0 (C-9), 20.8 (C-27), 19.8 (C-18), 
18.7 (C-30), 18.3 (C-21). ESI-MS m/z: 525.3560 $[\mathrm{M}+\mathrm{Na}]^{+}$, (calcd. for $\mathrm{C}_{31} \mathrm{H}_{50} \mathrm{O}_{5} \mathrm{Na}, 525.3556$ ). EIMS $m / z$ (relative intensity): $502[\mathrm{M}]^{+}(<1), 500$ (1), 469 (3), 455 (5), 419 (8), 397 (6), 371 (5), 328 (6), 327 (10), 313 (10), 293 (8), 261 (9), 241 (15), 235 (19), 201 (24), 188 (29), 175 (49), 161 (85), 148 (56), 134 (68), 120 (69), 105 (64), 91 (100), 77 (59), 67 (49).

\section{Preparation of compound 3}

A solution of compound $1(50 \mathrm{mg}, 0.11 \mathrm{mmol})$ in $\mathrm{EtOH}(8 \mathrm{ml})$ was added to $\mathrm{NaOH}(4.7 \mathrm{mg}$, $0.12 \mathrm{mmol}, 1.1$ equiv.), and then the reaction mixture was refluxed for $8 \mathrm{~h}$. Evaporation to dryness afforded a brown solid (77.0 mg). Purification by preparative TLC, eluted with $\mathrm{CH}_{3} \mathrm{COCH}_{3}$ :hexane (1:5), yielded compound 3 (35.9 mg, 70\%).

3: m.p. $210-213^{\circ} \mathrm{C}$. $[\alpha]_{589}^{25}-78.8$ (c 0.0102, $\left.\mathrm{CHCl}_{3}\right)$. UV $\lambda_{\text {max }}^{\mathrm{MeOH}} \mathrm{nm}(\log \varepsilon): 208$ (4.96). FTIR $(\mathrm{KBr}) v_{\max } \mathrm{cm}^{-1}: 3435,2954,2926,2872,1635$, 1558, 1415, 1384, 1272, 1153, 1021, 656. ${ }^{1} \mathrm{H}$ NMR (400 MHz, pyridine- $\mathrm{d}_{5}$ ) [21], $\delta: 6.04(1 \mathrm{H}, t, J=$ $6.9 \mathrm{~Hz}, \mathrm{H}-24), 3.26,2.65$ (2H, $m, \mathrm{H}-1), 2.90,2.79$ (2H, m, H-23), $2.29(2 \mathrm{H}, m, \mathrm{H}-11), 6.24(1 \mathrm{H}, d d$, $J=11.9,5.7 \mathrm{~Hz}, \mathrm{H}-5), 2.18$ (3H, $s, \mathrm{H}-27), 2.07$ (2H, $m, \mathrm{H}-7), 1.92(2 \mathrm{H}, m, \mathrm{H}-2), 1.79(1 \mathrm{H}, m, \mathrm{H}-$ 16), 1.76 (1H, $m, \mathrm{H}-6 \mathrm{a}), 1.68$ (1H, $m, \mathrm{H}-15 \mathrm{a}), 1.62$ $(2 \mathrm{H}, m, \mathrm{H}-12), 1.56(1 \mathrm{H}, m, \mathrm{H}-17), 1.56,1.16(2 \mathrm{H}$, $m, \mathrm{H}-22), 1.50(1 \mathrm{H}, m, \mathrm{H}-20), 1.51(3 \mathrm{H}, s, \mathrm{H}-29)$, $1.48(1 \mathrm{H}, m, \mathrm{H}-15 \mathrm{~b}), 1.48$ (3H, $s, \mathrm{H}-30), 1.38(1 \mathrm{H}$, $m, \mathrm{H}-8), 1.03$ (3H, $s, \mathrm{H}-18), 0.96$ (3H, $s, \mathrm{H}-28), 0.94$ (3H, br $d, \mathrm{H}-21), 0.83(1 \mathrm{H}, d, J=4.0 \mathrm{~Hz}, \mathrm{H}-19 \mathrm{~b})$, 0.77 (1H, $m, \mathrm{H}-6 \mathrm{~b}), 0.61(1 \mathrm{H}, d, J=4.0 \mathrm{~Hz}, \mathrm{H}-19 \mathrm{a})$. ${ }^{13} \mathrm{C}$ NMR (100 MHz, pyridine- $\mathrm{d}_{5}$ ): 177.7 (C-3), 171.4 (C-26), 143.0 (C-24), 129.3 (C-25), 75.7 (C4), 53.2 (C-17), 49.4 (C-5), 46.4 (C-8), 45.7 (C-13),

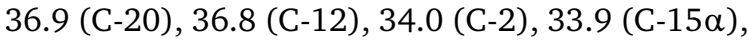
32.4 (C-22), 32.4 (C-30), 31.9 (C-19), 29.0 (C-6), 27.9 (C-7), 27.6 (C-16), 27.5 (C-10), 27.4 (C-23), 27.4 (C-29), 26.7 (C-11), 26.1 (C-1), 23.3 (C-27), 22.1 (C-9), 20.3 (C-28), 19.3 (C-21), 18.9 (C-18). ESI-MS m/z: $488.3505[\mathrm{M}]^{+}$, (calcd. for $\mathrm{C}_{30} \mathrm{H}_{48} \mathrm{O}_{5}$, 488.3502). EIMS $\mathrm{m} / \mathrm{z}$ (relative intensity): 488 $[\mathrm{M}]^{+}(<1), 461$ (1), $416(2), 385$ (2), 368 (7), 367 (4), 311 (4), 295 (7), 269 (5), 231 (8), 229 (12), 203 (17), 189 (12), 178 (27), 161 (32), 149 (63), 133 (33), 121 (55), 107 (56), 95 (59), 91 (70), 81 (100), 79 (82), 67 (71).

\section{Cell culture}

Human kidney-2 cells (HK-2 cells), the epithelial cell line derived from normal human renal proximal tubular cells, were obtained from American
Type Culture Collection (ATCC). They have been proved as a useful and good cell model to study the biology of renal proximal tubular cells. These cells have been shown to express glucose transporters including SGLT1 and SGLT2 $[22,23]$. HK2 cells were cultured in low glucose Dulbecco's Modified Eagle medium (DMEM) containing 10\% fetal bovine serum (FBS; Millipore), $100 \mathrm{U} / \mathrm{ml}$ penicillin, and $100 \mu \mathrm{g} / \mathrm{ml}$ streptomycin. Cells were incubated at $37^{\circ} \mathrm{C}$ in a humidified $5 \% \mathrm{CO}_{2}$ and 95\% air atmosphere and subcultured according to the ATCC's protocol. RPTEC/TERT1 cells, normal human renal proximal tubular cells, were obtained from ATCC cultured in 1:1 DMEM/F-12 nutrient mix supplemented with $5 \mu \mathrm{g} / \mathrm{ml}$ insulin, $5 \mu \mathrm{g} / \mathrm{ml}$ transferrin, $5 \mathrm{ng} / \mathrm{ml}$ sodium selenite, $100 \mathrm{U} / \mathrm{ml}$ penicillin, $100 \mu \mathrm{g} / \mathrm{ml}$ streptomycin, $10 \mathrm{ng} / \mathrm{ml} \mathrm{ep-}$ ithelial growth factor, and $36 \mathrm{ng} / \mathrm{ml}$ hydrocortisone. Cells were cultured routinely at $37^{\circ} \mathrm{C}$ in a $5 \% \mathrm{CO}_{2}$ and $95 \%$ humidified atmosphere.

\section{Cell viability assay}

Cell viability was evaluated by measuring the ability of cells using MTT assay. Cell viability was measured by using the reduction of MTT substrate to a purple formazan dye. Cells were seeded on 96well tissue culture microplates at $1.5 \times 10^{4}$ cells/well until confluence, and then the cells were incubated with tested compounds for $4 \mathrm{~h}$. After incubation, further $100 \mu \mathrm{l} /$ well of MTT solution $(0.5 \mathrm{mg} / \mathrm{ml}$ in serum-free medium) was added and incubated for $2 \mathrm{~h}$. The medium was removed, the formazan salt form was dissolved by $100 \mu \mathrm{l} /$ well of DMSO, and the absorbance at $540 \mathrm{~nm}$ was measured by microplate reader. The data were shown as percentage of cell viability compared with control group.

\section{Measurement of SGLTs expression}

RPTEC/TERT1 cells were lysed with modified RIPA lysis buffer and protease inhibitor cocktail for $20 \mathrm{~min}$, on ice, followed by $20 \mathrm{~min}$ centrifugation at $12000 \mathrm{rpm}$. Protein was resolved by sodium dodecyl sulfate polyacrylamide gel electrophoresis (SDSPAGE) and subsequently transferred to a nitrocellulose membrane by electro-blotting. Membranes were incubated with anti-SGLT1, anti-SGLT2 (Santa Cruz), and anti-GAPDH antibodies (Cell signaling) for overnight at $4^{\circ} \mathrm{C}$. The membranes were incubated with anti-rabbit HRP for $1 \mathrm{~h}$ and washed 5 times with TBST. The expressions of proteins were detected by using the enhanced chemiluminescence procedure. 


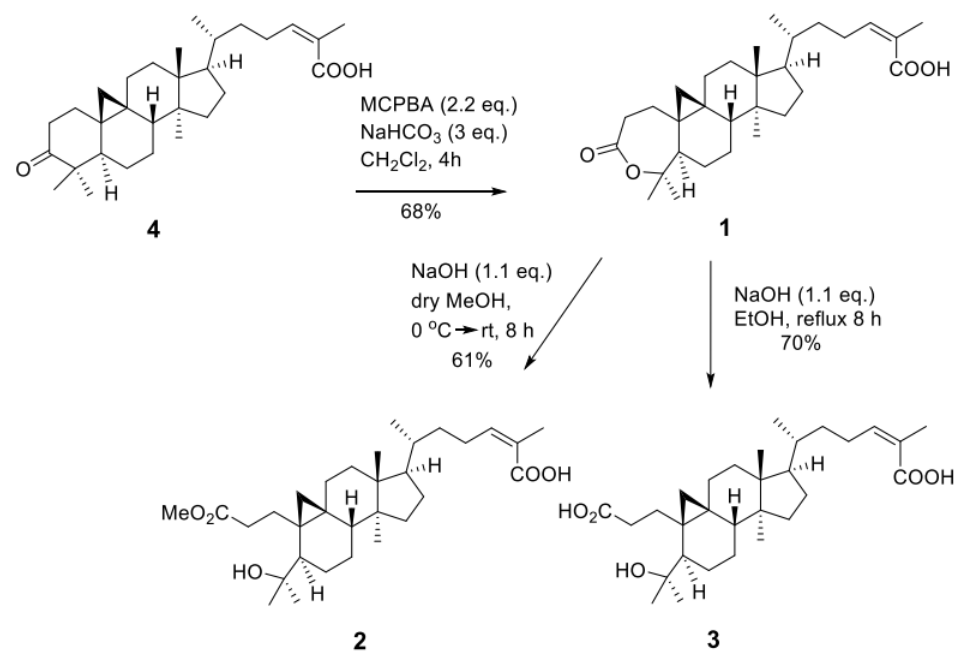

Fig. 1 Structure modification of schisandronic acid (4).

\section{Measurement of SGLT-mediated glucose uptake}

The glucose uptake was determined by measuring the cellular accumulation of ${ }^{3} \mathrm{H}-2 \mathrm{DG}$. HK-2 and RPTEC/TERT1 cells were seeded on 24-well plates until the cells became confluent monolayers. The cell monolayers were washed twice with $1 \mathrm{ml}$ of glucose transport buffer solution $(140 \mathrm{mM} \mathrm{NaCl}, 5 \mathrm{mM}$ $\mathrm{KCl}, 2.5 \mathrm{mM} \mathrm{CaCl}_{2}, 1 \mathrm{mM} \mathrm{MgSO}{ }_{4}, 1 \mathrm{mM} \mathrm{KH}_{2} \mathrm{PO}_{4}$, and $10 \mathrm{mM}$ HEPES) and then incubated for a further $15 \mathrm{~min}$. After pre-incubation period, $200 \mu \mathrm{l}$ of transport medium (glucose transport buffer containing $10 \mathrm{nM}$ of ${ }^{3} \mathrm{H}-2 \mathrm{DG}$ in the present of $10 \mu \mathrm{M}$ cytochalasin B, a GLUT inhibitor) was then added into each well. Cell monolayers were successively washed 3 times with $1 \mathrm{ml}$ of ice-cold transport buffer to stop the transport. The cells were solubilized with $0.4 \mathrm{M} \mathrm{NaOH}$ in $10 \%$ SDS for at least $4 \mathrm{~h}$ and then neutralized with $1 \mathrm{~N} \mathrm{HCl}$. The samples were transferred to scintillation vials for measurement of accumulated radioactivity. The glucose uptake is calculated as moles per square centimeter of surface area of the confluent monolayer.

\section{RESULTS AND DISCUSSION}

\section{Preparation of schisandronic acid derivatives}

Compounds 1-3 were prepared from schisandronic acid (4) as shown in Fig. 1. Baeyer Villiger oxidation of 4 with meta-chloroperbenzoic acid (MCPBA)/sodium hydrogen carbonate $\left(\mathrm{NaHCO}_{3}\right)$ in dichloromethane at room temperature for $4 \mathrm{~h}$ gave seven-membered ring lactone 1 . Cleavage of this lactone ring was further carried out by hydrolysis under 2 basic conditions. The first one was

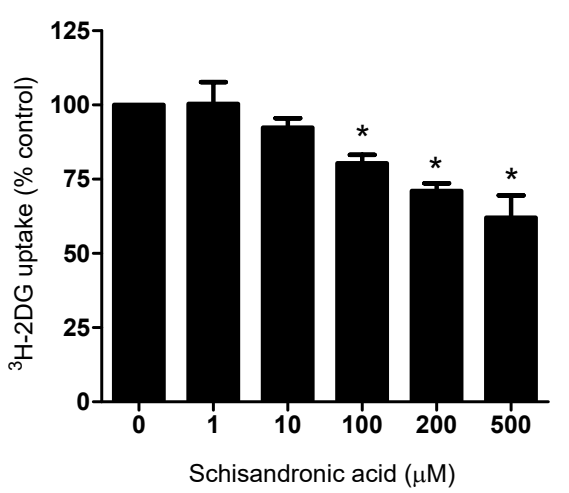

Fig. 2 Effect of schisandronic acid on ${ }^{3} \mathrm{H}-2 \mathrm{DG}$ uptake in HK-2 cells. HK-2 cells were incubated with glucose transport buffer containing $10 \mathrm{nM}{ }^{3} \mathrm{H}-2 \mathrm{DG}$ alone or in the presence of schisandronic acid at various concentrations for $20 \mathrm{~min}$. Error bars are mean $\pm \mathrm{SE}$ from 3 different experiments of control. $* p<0.05$ compared with no schisandronic acid.

treatment with sodium hydroxide in dry methanol at $0^{\circ} \mathrm{C}$, and the reaction mixture was left stirred at room temperature for a further $8 \mathrm{~h}$, leading to the formation of hydroxymethyl ester 2; the second one was hydrolysis in ethanol at reflux condition for $8 \mathrm{~h}$ yielding the hydroxycarboxylic acid 3.

\section{Biological activity}

An SGLT-mediated glucose uptake assay was performed to evaluate the inhibition potency of schisandronic acid and its derivatives. The glucose uptake was conducted in HK-2 cells that express SGLT1 and SGLT2 [22, 23]. As shown in Fig. 2, schisandronic 

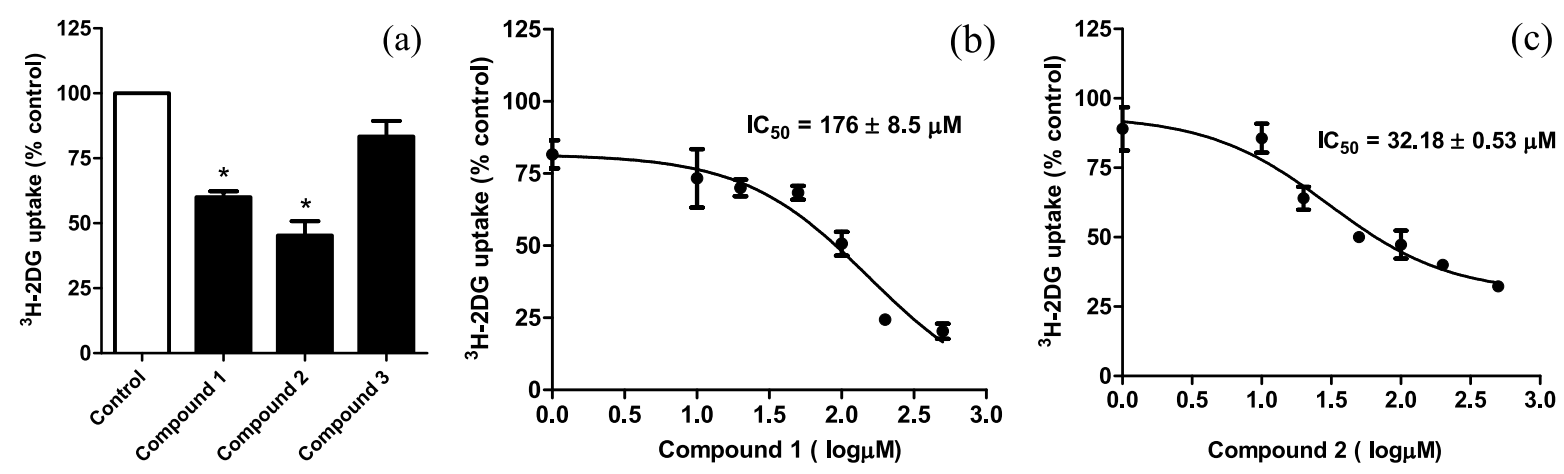

Fig. 3 Effect of schisandronic acid derivatives on ${ }^{3} \mathrm{H}-2 \mathrm{DG}$ uptake in HK-2 cells. HK-2 cells were incubated for 20 min with ${ }^{3} \mathrm{H}-2 \mathrm{DG}$ alone or with combined ${ }^{3} \mathrm{H}-2 \mathrm{DG}$ and schisandronic acid derivative at $100 \mu \mathrm{M}$ (a). Inhibitory potency of compound 1 (b) and compound 2 (c) on ${ }^{3} \mathrm{H}-2 \mathrm{DG}$ uptakes. The $\mathrm{IC}_{50}$ values were calculated from uptake measured in triplicate from 3 independent experiments. ${ }^{*} p<0.05$ compared with control $\left({ }^{3} \mathrm{H}-2 \mathrm{DG}\right.$ alone $)$.

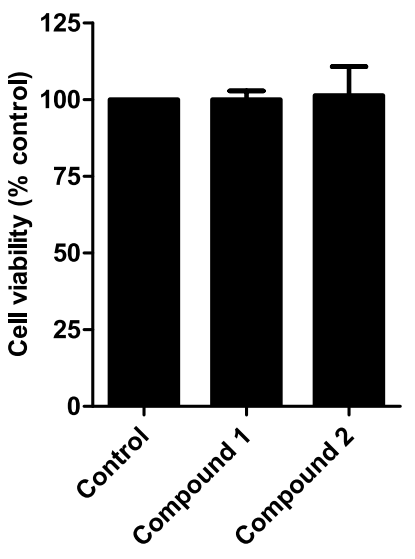

Fig. 4 Effect of schisandronic acid derivatives on cell viability. HK-2 cells were incubated with $100 \mu \mathrm{M}$ of compounds 1 and 2 for $4 \mathrm{~h}$, followed by measurement of cell viability using MTT assay. Error bars are mean \pm SE from 3 different experiments of control.

acid slightly inhibited glucose uptake in HK-2 cells at low concentration. Increase in concentration of schisandronic acid led to significant inhibition of ${ }^{3} \mathrm{H}-2 \mathrm{DG}$ compared with vehicle. However, the inhibitory potency of schisandronic acid was low. To determine whether the modified structures of schisandronic acid produced higher potency compared with schisandronic acid, the inhibitory effect of the derivatives of schisandronic acid, including compounds 1, 2, and 3, was determined. Only compounds 1 and 2 showed the significant inhibitions on SGLT-mediated glucose uptake in HK-2 cells (Fig. 3a). Dose-dependent inhibition of ${ }^{3} \mathrm{H}$ 2DG uptake in HK-2 cells was observed with increasing concentration of compound 1 or 2 . The $\mathrm{IC}_{50}$ of compound 1, obtained from a sigmoidal doseresponse model fit from the plot by the program GraphPad Prism, was $179 \mu \mathrm{M}$ (Fig. 3b). In similar experiments, compound 2 showed inhibition against SGLT-mediated glucose uptake in a dosedependent manner with an $\mathrm{IC}_{50}$ of $32 \mu \mathrm{M}$ (Fig. 3c). We further tested whether the inhibitory effect of compound 2 on glucose uptake was caused by cytotoxicity. The effect of compound 2 on mitochondria activity which reflects cell viability was performed by MTT assay. The results of $4 \mathrm{~h}$ treatment of HK-2 cells with $100 \mu \mathrm{M}$ of compound 2 showed that compound 2 had no cytotoxicity (Fig. 4). These results indicate the inhibitory effect of compound 2 on glucose uptake was not a result of cytotoxicity. The above results suggest that the compound with the ester functionality, either in the form of cyclic ester (lactone) or ring-opened ester, shows higher inhibitory effect on glucose uptake in HK-2 cells than the compound with carboxylic acid group. However, the inhibition on SGLT-mediated glucose uptake of the ring-opened ester seems to be more significant. The decrease in transport function of SGLT is mediated by reduction of transport activity of the transporter or decrease in protein expression. Although the effect of test compounds on expression of SGLT was not determined, we speculate that the compounds might affect transport activity occurring after short time incubation rather than affecting protein expression which presumably would need longer time to elicit the effect.

Although HK-2 cells showed characteristics of renal proximal tubular cells with expression of SGLT2, the cells also showed expression of SGLT1 [23]. Therefore, we cannot rule out the possibility that SGLT1 might contribute to the in- 
(a)
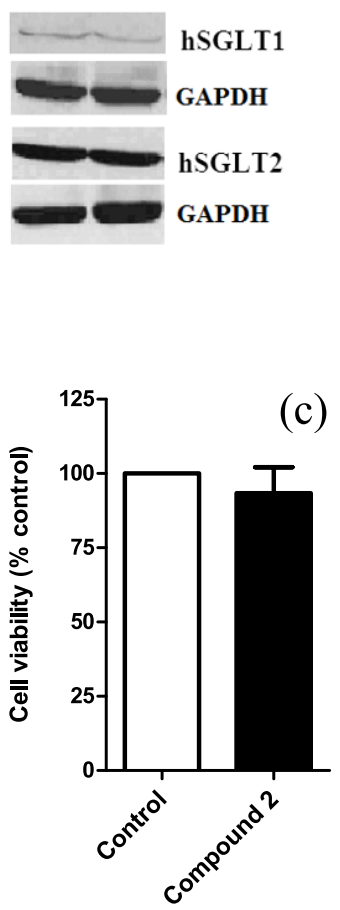
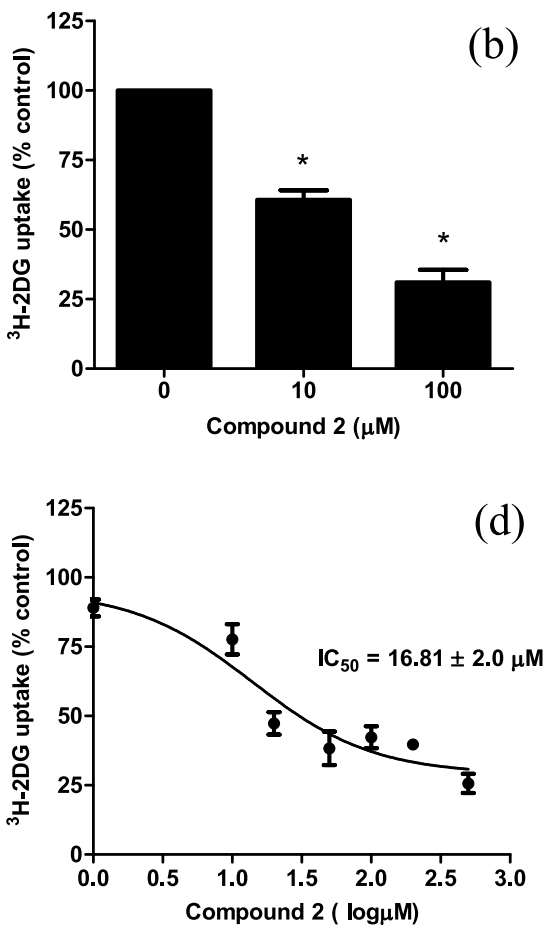

Fig. 5 Effect of compound 2 on ${ }^{3} \mathrm{H}-2 \mathrm{DG}$ uptake in RPTEC/TERT1 cells. (a) Representative blots of SGLT1 and SGLT2 expression in RPTEC/TERT1 cells. (b) Effect of compounds 2 on ${ }^{3} \mathrm{H}-2 \mathrm{DG}$ uptake in RPTEC/TERT1 cells. (c) Effect of compound 2 on cell viability: RPTEC/TERT1 cells were incubated with compound 2 for $4 \mathrm{~h}$. (d) Inhibitory potency of compound 2: the $\mathrm{IC}_{50}$ value was calculated from uptake measured in triplicate from 3 independent experiments. Error bars are mean \pm SE from 3 different experiments of control. * $p<0.05$ compared with control.

hibitory effect of compound 2 on glucose uptake in HK-2 cells. We next searched for human renal proximal tubular cell line expressing SGLT2 but not SGLT1. The present study investigated expression profile of SGLT1 and SGLT2 in RPTEC/TERT1 cells, a new model of human renal proximal tubular cells [20]. The Western blot analysis revealed that RPTEC/TERT1 cells mainly expressed SGLT2 while low expression of SGLT1 was observed (Fig. 5a). We next verified whether compound 2 inhibits SGLT2, inhibitory effect of compound 2 on ${ }^{3} \mathrm{H}-2 \mathrm{DG}$ in RPTEC/TERT1 cells. The results showed that compound 2 significantly inhibited ${ }^{3} \mathrm{H}-2 \mathrm{DG}$ uptake (Fig. 5b). Incubation of RPTEC/TERT1 cells with $100 \mu \mathrm{M}$ of compound 2 did not reduce the cell viability (Fig. 5c). These results indicated that the inhibitory effect of compound 2 for $4 \mathrm{~h}$ was not due to its cytotoxicity. It might be possible that compound 2 inhibited SGLT2 transport function. The inhibitory potency of compound 2 on SGLT2 activity was further determined. As shown in Fig. 5d, the $\mathrm{IC}_{50}$ of compound 2 found in RPTECT/TERT1 cells was $16 \mu \mathrm{M}$ that was less than that obtained from HK2 cells that express both SGLT1 and SGLT2 $(32 \mu \mathrm{M})$. This evidence implied that compound 2 might have higher affinity on SGLT2 than SGLT1. However, this phenomenon needs to be verified in single SGLT1 or SGLT2 expression system.

\section{CONCLUSION}

In this study, we have demonstrated that the derivatives of schisandronic acid with structure modifying as an ester form (compound 2) inhibited SGLTmediated glucose uptake, and the compound could be a new target for treatment of diabetes in human renal proximal tubular cells. As most of developed SGLT2 inhibitors are glycosides, this non-glycoside represents a new scaffold for SGLT inhibitors and may well serve as a novel hit compound of lead optimization.

Acknowledgements: This research project is supported by Center of Excellence Environmental Health and Toxicology (to Sunhapas Soodvilai). 


\section{REFERENCES}

1. Porte D (2001) Clinical importance of insulin secretion and its interaction with insulin resistance in the treatment of type 2 diabetes mellitus and its complications. Diabetes Metab Res Rev 17, 181-188.

2. Bailey CJ (2015) Safety of antidiabetes medications: An update. Clin Pharmacol Ther 98, 185-195.

3. Mudaliar S, Henry RR (1999) Combination therapy for type 2 diabetes. Endocr Pract 5, 208-219.

4. Phung OJ, Sobieraj DM, Engel SS, Rajpathak SN (2014) Early combination therapy for the treatment of type 2 diabetes mellitus: systematic review and meta-analysis. Diabetes Obes Metab 16, 410-417.

5. Tahrani AA, Barnett AH, Bailey CJ (2016) Pharmacology and therapeutic implications of current drugs for type 2 diabetes mellitus. Nat Rev Endocrinol 12, 566-592.

6. UK Prospective Diabetes Study (UKPDS) Group (1998) Effect of intensive blood-glucose control with metformin on complications in overweight patients with type 2 diabetes (UKPDS 34). Lancet 352, 854-865.

7. Brown GK (2000) Glucose transporters: structure, function and consequences of deficiency. $J$ Inherit Metab Dis 23, 237-246.

8. Chao EC, Henry RR (2010) SGLT2 inhibition-a novel strategy for diabetes treatment. Nat Rev Drug Discov 9, 551-559.

9. Panchapakesan U, Pegg K, Gross S, Komala MG, Mudaliar H, Forbes J, Pollock C, Mather A (2013) Effects of SGLT2 inhibition in human kidney proximal tubular cells-renoprotection in diabetic nephropathy. PLoS One 8, e54442.

10. Vallon V, Platt KA, Cunard R, Schroth J, Whaley J, Thomson SC, Koepsell H, Rieg T (2011) SGLT2 mediates glucose reabsorption in the early proximal tubule. J Am Soc Nephrol 22, 104-112.

11. Abdul-Ghani MA, DeFronzo RA (2008) Inhibition of renal glucose reabsorption: a novel strategy for achieving glucose control in type 2 diabetes mellitus. Endocr Pract 14, 782-790.

12. Malhotra A, Kudyar S, Gupta AK, Kudyar RP, Malhotra P (2015) Sodium glucose co-transporter inhibitors - A new class of old drugs. Int J Appl Basic Med Res 5, 161-163.
13. Chen Y, Men K, Meng C-m, Ma J, Guo J-c (2020) Changes in TLR-4 expression level and CD14+CD16+ monocyte ratio in the peripheral blood of patients with early diabetic nephropathies. ScienceAsia 46, 206-212.

14. Takahashi K, Takani M (1976) Studies of constituents of medicinal plants. XVII. Constituents of Schizandra nigra Max. and their carbon-13 nuclear magnetic resonance spectra. Chem Pharm Bull (Tokyo) 24, 2000-2006.

15. Sy LK, Brown GD (1998) A prezizaane sesquiterpene from Illicium angustisepalum. Phytochemistry 49, 1715-1717.

16. Chen YG, Qin GW, Cao L, Leng Y, Xie YY (2001) Triterpenoid acids from Schisandra propinqua with cytotoxic effect on rat luteal cells and human decidual cells in vitro. Fitoterapia 72, 435-437.

17. Chen YG, Wu ZC, Lv YP, Gui SH, Wen J, Liao XR, Yuan LM, Halaweish F (2003) Triterpenoids from Schisandra henryi with cytotoxic effect on leukemia and Hela cells in vitro. Arch Pharm Res 26, 912-916.

18. Xu LJ, Huang F, Chen SB, Zhang QX, Li LN, Chen SL, Xiao PG (2006) New lignans and cytotoxic constituents from Schisandra propinqua. Planta Med 72, 169-174.

19. Xu LJ, Peng ZG, Chen HS, Wang J, Xiao PG (2010) Bioactive triterpenoids from Kadsura heteroclita. Chem Biodivers 7, 2289-2295.

20. Ha do T, Tuan DT, Thu NB, Nhiem NX, Ngoc TM, Yim N, Bae K (2009) Palbinone and triterpenes from Moutan Cortex (Paeonia suffruticosa, Paeoniaceae) stimulate glucose uptake and glycogen synthesis via activation of AMPK in insulin-resistant human HepG2 Cells. Bioorg Med Chem Lett 19, 5556-5559.

21. Wieser M, Stadler G, Jennings P, Streubel B, Pfaller W, Ambros P, Riedl C, Katinger H, et al (2008) hTERT alone immortalizes epithelial cells of renal proximal tubules without changing their functional characteristics. Am J Physiol Renal Physiol 295, F1365-1375.

22. Kothinti RK, Blodgett AB, North PE, Roman RJ, Tabatabai NM (2012) A novel SGLT is expressed in the human kidney. Eur J Pharmacol 690, 77-83.

23. Solocinski K, Richards J, All S, Cheng KY, Khundmiri SJ, Gumz ML (2015) Transcriptional regulation of NHE3 and SGLT1 by the circadian clock protein Per1 in proximal tubule cells. Am J Physiol Renal Physiol 309, F933-942. 